\title{
Economic empowerment of rural women for enhancing household income \& health security- lessons from studies in Andhra Pradesh, Karnataka, Kerala, Tamil Nadu and Kenya
}

\author{
Vijayakhader
}

\author{
Dean, Faculty of Home Science(Retired), Acharya N. G. Ranga Agricultural University, Hyderabad, Telangana, India
}

*Corresponding Author:

Email:Vijayakhader@gmail.com

\begin{abstract}
Intervention of various technologies to improve the food \& nutritional status of the population proved the following facts: Promotion of malt based small scale food industry not only provides opportunity for rural women to develop entrepreneurship and employment, but also provides food and nutritional security through income generation. To address this several technologies were developed under NATP like value addition to fish \& prawn products, artificial pearl culture, processing of salted fish, which helped the self help group women of Andhra Pradesh, Karnataka, Kerala and Tamil Nadu to improve their economic status. Received two patents \& licensed the technology which helped the women to reduce their drudgery and also preserve the fresh fish for a longer time without getting spoiled. Product development can be taken as income generating activity in the rural areas by the illiterate women. Products can be included in supplementary feeding programs in order to improve the nutritional status of the vulnerable groups of the population. The horse gram which is commonly used for cattle feed can be diversified for human consumption with less investment. Mothers as well as Anganwadi workers preferred amylase rich supplementary foods which reduced Grade III and grade IV malnutrition in Pre- school children significantly. The studies revealed that spawn multiplication can be done by women as a co-operative venture and mushroom cultivation can be undertaken at household level as an incomegenerating activity. Introducing red palm oil is beneficial to overcome vitamin A deficiency. Formers are encouraged to grow back yard nutrition garden. Iron enriched chewing gum consumption improved the Iron nutritional status of boys \& girls (2-16 years of age). After supplementation, morbidity rate decreased to $50 \%$ in preschool children, pregnant women and lactating women. The most important factor underlying the current nutritional situation in the country is poverty. Eradication of poverty and removal of socioeconomic disparities pose the most formidable challenge for improving the nutrition and health standards of the population. Impact of women's supplementary income on family's nutritional status showed that the supplementary income of women has a positive impact on the socioeconomic status of the family. This impact is particularly felt on the food and nutrient intake of the family contributing towards food \& Nutrition security.
\end{abstract}

Keywords: Product Development, Evaluation, Technology Intervention, Food Security, Nutrition Security, Health Security, Livelihood Security, Economic Empowerment.

\section{Introduction}

India is the second most populous country in the world; 120 million women live in poverty. Over 70 percent of India's population - livelihood from land resources (includes $84 \%$ of the economically-active women). Population increased- from 1951- 361.1 million to 2011- 1027 millions 933/1000 Female \& Male sex ratio, $22.8 \%$ adolescent girls, $16 \%$ BPL families, $70 \%$ land based livelihood, $84 \%$ women Agrl. Labourer, $75 \%$ male and $54.2 \%$ female literacy $(21.7 \%$ gap in literacy), $14 \%$ male and $15 \%$ female child labour, 54\% child marriages, $65 \%$ hidden hungerwomen and children. Gender disparities in nutrition from infancy to adulthood. Anemia in girls of 6-14 years is $95 \%$. As per the National and Regional Survey: Prevalence of anemia $74 \%$ in children below 3 years of age, $85 \%$ in pregnant mothers, $90 \%$ among adolescents girls. India's maternal mortality rate in rural areas highest in the world. Antenatal care- $40-50 \%$ of women, pregnancy related deaths- one-quarter of all fatalities. Gynecological disorder-92 percent suffered from one or more. Most vulnerable sections are
Adolescent girls, Pregnant and lactating mothers, under weight children under five.

\section{India is a strategic player in the world in the food sector}

Is the second largest producer of fruits and vegetables next to China, Second largest producer of wheat, Third largest in food grains (210 million tonnes) Largest exporter of cashew nut in the world (Amounts $43 \%$ of world production), Fifth largest producer of eggs, largest producer of milk $(91$ million tonnes).Working conditions result in premature and stillbirths, Impact of air and water pollution and lack of sanitation. Receive far less education than men; largest population of non-school working girls. Literacy rate for women is 39 percent versus 64 percent for men. Encouragement to private colleges will reduce women's opportunities for higher education since privatization in education promotes only male-dominated professional and technical courses. Sex-selective abortion, 96 percent of female fetuses was aborted. Indian women in the poverty group, spends about $5 \mathrm{hr} /$ day more than the Indian men in work. Taking the economy as a whole, 
women perform two-thirds of the work, but earn only one-tenth of the income. More than 250 million children in developing countries are at risk of Vitamin A deficiency, More than 2000 million women \& children are at the risk of iron deficiency, and More than 1500 million people in the World are at risk of iodine deficiency. Cost of Treating Malnutrition is 27 Times More Than the Investment required for its prevention. The annual wastage of agricultural produce is almost $30 \%$ and equivalent to Rs. 580 corers (Due to inadequate storage and processing facilities). According to India's $3^{\text {rd }}$ National family health survey Child Nutrition Below 5 years Age: 48\% - Stunted; 20\% Wasted; 43\% - Under weight; 70\% - Anemia; 50\% Vitamin A deficiency and 75\% - Iodine deficiency .India has not achieved acceptable child nutrition levels. People in 33 countries consume less calories than required. Food insecurity is due to lack of access and mal distribution. WHO \& World Economic Forum reviled India will incur an accumulated loss of \$236.6 billion by 2015 on account of unhealthy life style and faulty diet.

\section{Gender welfare programs}

1st to 5th Five -Year Plan (1951-1979) Welfare Approach.; 6th Five -Year Plan (1980-1984) Welfare to Development. DST starts the scheme "S\&T for Women" (1981); 7th Five -Year Plan (19851989)Department of Women \& Child Development setup (1985)Nodal Department; 8th Five -Year Plan (1992-1997), National Commission for Women setup (1992) ,-Women Development Corporation setup in states ;-India ratifies the Beijing declaration (1995); 9th Five - Year Plan (1997-2002); Development to empowerment, Women Component Plan adapted ensures not less than 30\% funds are earmarked for Women related activities in all Ministries. Scheme on Biotechnology Application for Women setup by DBT. Women Empowerment Year celebrated - 2001; 10th Five - Year Plan (2003-2007). S\&T Policy 2003 released by Ministry of Science and Technology Scholarship Scheme for Women, Scientists launched Women Scientists Cell setup at DST. 11 ${ }^{\text {th }}$ Five-Year Plan (2007-2012) Lower gender gap, reduce infant mortality rate, reduce maternal mortality rate, equal access to women to health care, education and vocational guidance.

\section{Economic growth in India has failed nutrition}

At current rates India will not meet the millennium development goal until 2043 not 2015 as planned. China has already met its 2015 target. China has reduced child under nutrition by more than half (from $25 \%$ to $8 \%$ ). Brazil has reduced child under nutrition by $60 \%$ (from $18 \%$ to $7 \%$ ). Thailand has reduced child under nutrition by more than half (from 50\% to $25 \%$ ) Viethnam has reduced child under nutrition by $40 \%$ (from $45 \%$ to $27 \%$ ). Reducing malnutrition is not just about health, agriculture and economics but it also accounts for politics, Governance and power.

\section{Several Programs}

National Nutrition Policy (1993); National Nutrition Plan of Action (1995); National Nutrition Mission (2001) not at achieved nutrition goals .Reasons: Nutrition is a poor cousin even in health and agriculture planning and execution, Nutrition improvement is not a stated goal with measurable parameters in National Food Security Mission, National Horticulture Mission and National Rural Health Mission.

The Most important National Nutrition Programmes in India are Integrated child Development services program (ICDS) ,The targeted public distribution system (TPDS) ,Food for work ,The National Mid, Day meals program (NMMP) ,Micro nutrient (Iron folate; Vitamin A; Iodized salt) schemes . Research carried out by Vijayakhader on: 1) Rural Development; 2) Women Empowerment; 3) Food Security \& Lively Hood Security to improve the Nutritional Status is discussed below.

Experimental methodology used starting from Surveys, Chemical analysis, Biochemical estimations, bio-availability studies on rats as well as human subjects; clinical observations and histological studies were used as per the study design. Product development, value addition, Technology transfer, Entrepreneur skills development, income generation activities and creating awareness through Nutrition Education were also used.

1. Home based low cost energy protein rich preparations using Horse gram for vulnerable groups (Vijayakhader \& P.Ashlesh, 1998): The horse gram which is commonly used for cattle feed can be diversified for human consumption with less investment. Processed horse gram flour was prepared using Puffing and Roasting, Processed Soyabean flour was prepared by Dehulling and Roasting. The low cost energy protein rich products namely RAGINA and EPRF were prepared using the simple home scale processing methods like germination, roasting and puffing, to improve the nutritional status. Horse gram has been identified as potential food resource for the tropics and also occupies an important place among pulses because of its ability to resist severe drought conditions. Soya bean (Glycine max) is one of the best vegetable proteins and has tremendous potential to meet the protein deficiency in the cereal based Indian Diets at a low cost. Product development can be taken as income generating activity in the rural areas by the illiterate women. Products can be included in supplementary feeding programmes in order to improve the nutritional status of the vulnerable groups of the population. 
2. Effect of Iron enriched chewing gum/Bubble gum consumption on Iron nutritional status of anemic adolescent boys \& girls" Age range of 12-16 Yrs (Vijayakhader \& Shoba, 2008): This project was taken up to test if a commonly consumed product like fortified chewing gum could be given to overcome iron deficiency among adolescents. Results showed to improve the Iron Nutritional Status of 60 Boys \& 60 girls in the age 12-16 years at Kondurgu village of Mahabbobnagar District. The study proto cal was approved by the Institutional Ethical committee of the college. Children were given either unfortified or fortified chewing gum thrice a day and the iron nutritional status was measured at three points of time at base line ; mid point and end point in a study period of 180 days. The consumption of fortified Chewing gum improved the Hemoglobin levels. Long term storage studies are in progress.

3 To study the effect of feeding malted food on the nutritional status of vulnerable groups (Vijayakhader \& Umamaheswari, 2012): Amylase Rich Malted Mixes (ARMM) two types were formulated using Ragi / Wheat and suitable products namely Laddu, Roti, Kheer, and Porridge were prepared using formulated malted mix. The ARMM's found to be nutritional dense. For the supplementation of malted mixes 8 villages of Lepakshi Mandal, Ananthapur District was selected. Preschool children (400), pregnant women (100) and Lactating women (100) were selected and fed with two types of malted mixes (Ragi / Wheat) for a period of 3 months. Anthropometric data, Food intake showed a significant increase in the preschoolers, pregnant women and Lactating mothers. Clinical assessment showed considerable reduction i.e. (50\%) in nutritional deficiency symptoms and morbidity rate of all the subjects. Training programmes were conducted to 40 members by lecture and method demonstrations using developed education material such as Posters, Flip book, Manual and CD-Rom. After the training $60-70 \%$ improvement was observed in Knowledge, Attitude and Practices scores of the trainees, project profile for bulk production was also developed. Supplementation of ARMM's helped to improve the nutritional status of the vulnerable groups of population in rural areas especially with regard to protein, energy, iron, and calcium and B-complex vitamins. Promotion of malt based small scale food industry not only provides opportunity for rural women to develop entrepreneurship and employment but also provided Food and Nutritional Security through income generation.

4 Therapeutic food supplementation in ICDS projects of Andhra Pradesh (Yasoda Devi \& Vijayakhader, 2004): Total 2267 children of age range of 1-3 years were selected (892 children from rural ICDS project, Saravakota; 507 children from new ICDS project, Kottem; and 778 children from tribal ICDS project, Seethapeta) for a period of 1 year. The three types of supplements were prepared and distributed by A.P. Foods, Hyderabad. The supplements were distributed either in the form of Laddu or as in the form of powder. Nutritive value of $100 \mathrm{~g}$ of supplements provides 400 to $480 \mathrm{Kcal} 12.5$ to $13.8 \mathrm{~g}$ proteins.

It was very encouraging to note that $92 \%$ of grade III children showed improvement in their weight and height; $80 \%$ of moderately malnourished; $42 \%$ of mildly malnourished and $44 \%$ with normal grade showed improvement. It was also observed that there was positive correlation between the calorie and protein intake and also improvement in weight and height. All $100 \%$ of mothers as well as Anganwadi workers preferred these supplementary foods better as compared to earlier supplied food i.e. ready to eat food.

5 Studies on Fisher Women in the Coastal Eco System of Andhra Pradesh, Karnataka, Kerala and Tamil Nadu (Vijaya Khader, R.N. Kumar, J.Lakshmi, K.Dhanapal, H.M.Kasim, R.Sathiadas and N.S.Sudhakar. 2004): Two Equipments I) Low Cost Ice Cream Freezer II) Fresh Fish Vending and Display Table have been fabricated and the patents were received on 13th October, 2003. The technology has been licensed to Smt.G.Varalakshmi, W/o. Sri G.Satya Kiran, $\mathrm{M} / \mathrm{s}$. Yogi Industries, and Secunderabad for manufacturing these two equipments for a period of two years. She is the sole authority to manufacture in the country. After expiry of two years the technology on low cost ice cream freezer was licensed second time to another women entrepreneur namely Mrs. Lakshmi Bhuvaneswari W/o Devi Hariprasad, D.No.23/321, Bachupeta, Hindu College Road, Machilipatnam - 527001 on 16th September, 2006 for a period of 6 years. These equipments were fabricated mainly to improve the Health Security.

6 Role of Women in Fisheries in Coastal EcoSystem of Andhra Pradesh, Karnataka, Kerala and Tamil Nadu. (Vijaya Khader, R.Sathiadas and H.Mohamad Kasim - 2005): Fish eaters in the study area comprise 47 per cent of the total population ranging from 237 per cent in Tamil Nadu to 85 per cent in Kerala. Though the position of Tamil Nadu in terms of number of coastal districts and possession of coast line including the number of landing centers is envious, the number of fish eaters in the state is minimal. Andhra Pradesh employs 32 per cent of its fisherwomen in fish curing/drying/net making and 27 per cent in processing plant works. 
7 Tribal mother's attitude towards lactation performance (Vijayakhader, Vimala, Sarojini \& Rajya Lakshmi, 1996): Tribal women are mostly involved in food preparation $(25 \%)$ where as men are involved in occupational activities. Majority $(85 \%)$ of tribal women do not think lactation as a necessity to take special care about either food because they were lactating. Majority of mothers $(66 \%)$ were aware of the reason for decrease in lactation performance. Only a small number of mothers $(5 \%)$ knew that sickness and insufficient food $(2 \%)$ played a role in decreasing the lactation performance. As nursing mothers, they do not receive any special attention from the family members regarding the additional intake of food. A positive change was observed in lactating mothers through Nutrition Education.

8 Health Status of Tribal's of Chinthapalli Block (Vijayakhader, Vimala,Sarojini \& Rajya Lakshmi ,1996): Health problems of the tribal's are related to number of factors which include illiteracy, ignorenceof the disease and its prevention,poverty,poor nutritional status Poor environmental sanitation and poor personal hygiene, non availability of safe drinking water, which make people more vulnerable to infections. Superstitions and beliefs add to the health problems and complicate the situation. Malnutrition leading to tuberculosis and goitre are major disease in tribals. Vomiting; diarrhoea and consequent dehydration are causes for death among infants and children. Skin diseases especially scabies and heat boils are common.

9 Effect of Jawahar Rojgar Yojana Programme during lean season on the Nutritional Status of Women in Landless Labour Families of Drought prone areas (Uma Maheswari and Vijaya Khader - 2001): The study was conducted in eight villages of four interior Mandals having low rainfall $(500-750 \mathrm{~mm})$ in Ananthapur a drought prone district of Andhra Pradesh. A household survey was conducted to screen the families having at least one women of child bearing age from the eight selected villages of the four Mandals. A total of 120 families were selected for the study of which 60 families were JRY beneficiary families' where at least one member of the family was being employed under JRY scheme and 60 families were non-JRY beneficiary families. The study showed that the additional income gained by the landless labourer families during the lean season from Jawahar Rojgar Yojana (JRY) programme had beneficial effect on the nutritional status as assessed by the anthropometric measurements as well as clinical observations. The results indicated the past malnutrition status of the population in Ananthapur district because of the repeated and prolonged droughts.
10 Effect of Jawahar Rojgar Yojana scheme during lean season on the Expenditure (Uma Maheswari and Vijaya Khader -2001a): A significant positive trend towards improvement in the quality of food taken by the landless labour families with the additional income generated through welfare programme i.e., Jawahar Rojgar Yojana in lean season as evinced by better food and non-food expenditure pattern of the JRY beneficiary families over the counterpart non JRY families in dry land and drought prone areas of Ananthapur district, Andhra Pradesh.

11 Coping mechanisms adapted for food security at household level in drought prone areas of Ananthapur, Andhra Pradesh (Uma Maheswari \& Vijaya Khader, 2003): A study was carried out in eight villages of four interior Mandals having low rainfall (500-750 mm), in Ananthapur a drought prone district of Andhra Pradesh. Families having at least one women of child-bearing age were enumerated. Two rounds of survey were conducted to understand the difference in coping mechanisms operating between peak and lean seasons. The study centered around the empirical examination of eight major groups of coping mechanisms comprising of land, livestock, economic, food procurement and production, food consumption and distribution, food storage, social and health based mechanisms adapted by the families. The various economic activities under taken by the women in the study area included Agriculture, Agriculture labour, basket making, Beedee making, brick making, broom making, cattle rearing, firewood collection, flour mill, fodder collection, forest produce collection, goat / sheep rearing, laundering, mat weaving, nonagricultural labour, petty trade, pottery, poultry rearing, ring making, sericulture, tailoring, tamarind peeling, vegetable vending and weaving clothes etc. Most often children especially girls were involved in home based trades like groundnut shelling, beedi making, tamarind peeling etc. A few of the mechanisms were found to be beneficial and can be encouraged.

12 Rural Women as Entrepreneurs in Mushroom Cultivation (Vijaya Khader, 1994): Every woman is an entrepreneur as she manages, organizes and assures responsibility for running her house. It has been increasingly realized that women possess entrepreneurial talent which can be har nessed to create employment opportunities. In the rural areas a woman can easily manage $4-10$ beds depending on the space available, helping them to earn Rs. 180 to Rs. 450 per month. The results of the studies revealed that spawn multiplication can be done by women as a co-operative venture and mushroom cultivation can be undertaken at household level as an income-generating activity. 
13 Family income and nutritional status of prescholars' in rural areas of Tenali division (Vijayakhader \& Kavitha, 1993): The increase in the annual per capita income of the family increased slightly the nutritional status of prescholars .The results also reveal that no significant difference was observed between the body weight of children and income of the parents in all the age group. In spite of having high purchasing power, lower educational status of the mothers and also low nutritional awareness, majority of the children are in Grade 1 degree malnutrition.

14 Transfer of home level preservative techniques of selective fruits and vegetables to rural women in Guntur district (Vijaya Khader and Bharathi, 1994): There was a significant, negative correlation between age of the respondents and gain in knowledge .There was a significant positive correlation of socio economic variables such as educational status, family income, and land holding on gain in knowledge.

15 Operational feasibility of RPO supplementation to pre-school children in Anganwadi centers of ICDs Project (Vijayakhader and Aruna, 2008): Vitamin A deficiency causes many health problems especially among children. A study was undertaken to screen the effect of supplementation of Red Palm Oil (RPO) obtained from the fruits of tree Leis guineensis Jac.The oil is rich in B-carotene, a precursor of Vitamin A.

Supplementation of crude RPO to Anganwadi Children increased the attendance of children, increase in heights and weights of children. Decrease in Grade 11 and Grade 111 malnutrition was observed in respect of sex.

16 Impact of women's supplementary income on families' nutritional status (Vijaya Khader, 1999): The Study was carried in 4 villages of Rajendranagar Mandal and Ranga Reddy District (Vegetable venders, Agarbathi labourers, Shopkeepers, Washers, Fruit venders, Tea and Snack workers. The results reveal that the supplementary income of women has a positive impact on socio-economic status of the family. This impact as felt on food and nutrition in take of the family.

17 Impact of dairy programme on the nutritional status of women and preschool children in Vihiga District, Kenya Africa (Mary Khakoni Walingo \& Vijayakhader, 2000): The dairy programme in Kenya has a significant impact on the overall improvement of the family in specific to improving production, consumption and marketed surplus of milk. Food and nutrient intake and nutritional status of women and preschool children from participant households improved. The prevalence of under nutrition in pre school children in participant households was lower $(1.7 \%)$ than that of children in non participant households(2.9\%).Stunting was $8.7 \%$ and $21.4 \%$ in preschool children from participant and nonparticipant households respectively. Less percent $(6.7 \%)$ of women in participant households had body mass index less than 18.5 , wheras $7.3 \%$ of women from non- participant households fell below this cut - off point.

\section{Success Stories}

The National Agricultural Technology Project entitled Studies on Fisherwomen in coastal ecosystem of Andhra Pradesh, Karnataka, Tamil Nadu and Kerala explored the socio-economic status of fisherwomen and found the families wherein women are actively involved in one or other occupation has flourished and achieved all round development. Seven Fisherwomen ( 3 from Kerala ;2 from Karnataka and 2 from A.P) have attained the Training and Awareness from National Agricultural Technology Project, implemented in their places and enhanced their socio-economic status through various skill oriented training programmes and continuous day-to-day discussions with the Scientists.

\section{Impact of Research / Summary}

Based on Vijayakhader work, Commissioner of Horticulture has issued the G.O. on unit cost for Oyster Mushrooms cultivation Rs. 70,000/- by NABARD and implemented from 1st August 1994 onwards (many people have availed the benefit) 41 families have established mushroom cultivation in Guntur, Prakasham and Krishna Districts of Andhra Pradesh;10 families have taken fruit and vegetable processing at village level ;3 families have adopted the technology of Dehulling jowar and preparing value added products; 10 self help groups have been organized at Karnataka and Kerala are mainly involved in various income generating activities. Mrs Laura Bush, the First Lady of USA had discussions with Mrs Khader on 3rd March 2006 for 2 hours on food processing, income generating activities and gender issues.

The Deccan Development Society (DDS) NGO in Medak District, Andhra Pradesh are using the millet based recipies in feeding programme in 8 villages for Anganwadi children ( 3 to 5 years age).

Technologies Developed ready for commercialization

Entrepreneurship Technologies: Sorghum Food Enterprise / Geriatric Foods / Malted Infant Foods / High Fiber Vermicelli / Preservation of Palmyra Palm Fruit / Mushroom Cultivation.

Knowledge Empowerment Technologies: Multipurpose fresh fish Vending \& Display Table / Low Cost Ice-cream Freezer

Value Addition Technologies: Value addition to Fruits / Value addition to Red Palm Oil / Fruit Powders / Horse gram Products \& Soya Products. 


\section{Recommendations / Suggestions}

1. Improve the Productivity \& Profitability of Small holdings through appropriate technologies and market linkages

2. Encourage the scope for the growth of Agro Processing, Agro Industries and Agri Business

3. Promote opportunities for the services sector to expand in a manner that will trigger the technological and economic up gradation of farm operations

4. Start agri-clinics and agri. business centers

5. The home science graduates can pay particular attention to nutrition and food safety and processing, and help a group of farm women to start food processing and health food parks

6. Young Entrepreneurs for initiating programme in the phase of soil health enhancement, Plant and Animal Health Care, Seed Technology \& Hybrid Seed production are several.

7. Operate climate Risk Management Centers, are the path way to sustainable agriculture and food security as well as agrarian prosperity.

To conclude Take science to women and women to science for country's proper growth and development.

\section{References}

1. Vijayakhader \& P. Ashlesh(1998) Home based low cost energy protein rich preparations using Horse gram (Dolichos Biflorus) for vulnerable groups Indian Oil Palm Journal, Vol. VIII, No.46, pp.13-17

2. Vijayakhader \& Umamaheswari (2012) to study the effect of feeding malted food on the nutritional status of vulnerable groups: accepted for publication in the International Journal for Biotechnology and Molecular Biology Research.

3. Yasoda Devi \& Vijayakhader (2004)Therapeutic food supplementation in ICDS projects of Andhra Pradesh ,Every man's science Vol.39(3)160-167

4. Vijaya Khader, R.N. Kumar, J. Lakshmi, K. Dhanapal, H. M. Kasim, R. Sathiadas and N.s Sudhakar (2004 )Studies on Fisher Women in the Coastal Eco System of Andhra Pradesh, Karnataka, Kerala and Tamil Nadu,World Fish centre, Global Symposium on Gender and Fisheries Seventh Asian Fisheries forum, P.No.69-79, Penang, Malaysia.

5. Vijaya Khader, R. Sathiadhas and H. Mohammad Kasim ( 2005)Role of Women in Fisheries in Coastal EcoSystem of Andhra Pradesh, Karnataka, Kerala and Tamil Nadu; J. Res ANGRAU 33(1) 53-59.

6. K. Uma Maheswari and Vijaya Khader (2001)Effect of Jawahar Rojgar Yojana Programme during lean season on the Nutritional Status of Women in Landless Labour Families of Drought prone areas - J. Dairying. Foods \& H.S. 20 (1) : 58-61

7. Mary Khakoni Walingo and Vijayakhader (2000). Impact of Dairy programme on the Nutritional status of women and pre-school children in Vihiga district --- (Ph.D. thesis)

8. Uma Maheswari K. and Vijaya Khader (2003) A study on coping mechanisms adopted for food security at Household level in Drought prone areas of Ananthapur, A.P., J.ResearchANGRAU,31(2)127-130.

9. Uma Maheswari and Vijaya Khader (2001 a)Effect of Jawahar Rojgar Yojana scheme during lean season on the
Expenditure (Food and Non-Food) pattern of Landless Labour Families in Drought prone areas of Ananthapur district, Andhra Pradesh - Economic Affairs, Vol.46, Qr.2, June.

10. Vijayakhader and Kavitha (1993) Anthropometric measurements of pre-school children in the rural areas of Tenali division. Asian Journal of Psychology and Education. Vol.26 No.1-2, PP.35-40.

11. Vijayakhader and V.V. Bharathi (1994) Transfer of Home level preservative techniques of selective fruit and vegetables to rural women in Guntur district. Asian Journal of Psychology and Education. Vol.27 No.3-4, PP.1-11.

12. Vijayakhader (1996) Studies on nutritional awareness of Mothers and Child mortality rate in selected urban slums and rural areas of Guntur district. The Andhra Agric.J.43 (2-4) 174-178.

13. Vijaya Khader (1999) Impact of Women's supplementary incomes as families' Nutritional status. The Indian Journal Social Work, vol. 60(3) 368-378.

14. Vijaya Khader (1994) Rural Women as Entrepreneurs in Mushroom Cultivation, Indian Farming, March, 18-21.

15. Vijayakhader and Aruna (2008) Operational feasibility of RPO supplementation to pre-school children in Anganwadi centers of ICDs Project, Natural Product Radiance, and Vol.7 (4) pp 310-313.

16. Vijayakhader \& Shoba( 2008)Effect of Iron enriched chewing gum/Bubble gum consumption on Iron nutritional status of anemic adolescent boys \& girls" Age range of 12-16 Yrs (under Process)

17. Vijayakhader, V. Vimala, G, Sarojini and P. Rajyalakshmi(1996 )Tribal's of Andhra Pradesh and their Nutritional Status, Book published by Andhra Pradesh Agricultural University, Rajendranagar, Hyderabad-30. 